\title{
Planning Of Beef Cattle Development in District Blora, Central Java, Indonesia
}

\author{
Budi Santoso ${ }^{1 *}$, and Bambang Waluyo Hadi Eko Prasetiyono ${ }^{2}$ \\ ${ }^{1}$ Master Program of Environmental Science, School of Postgraduate Student Diponegoro University \\ ${ }^{2}$ Animal Sciences Dept, Faculty of Animal and Agriculture Sciences, Diponegoro University
}

\begin{abstract}
Continuity of meat supply availability is generally related to the number and production of livestock in a region. Therefore, a framework of sustainable livestock development is needed to increase the production and productivity of livestock. Blora Regency is one of the areas in the Province of Central Java with the largest number of large livestock, primarily beef cattle. Blora Regency has a population of 199.584 beef cattle. Agricultural waste results in Blora Regency can be used as supporting the availability of feed for livestock sector. This is supported by the availability of forage feed which is very abundant.Based on these potentials, it is necessary to assess the characteristics of natural land for the development of beef cattle farms. Therefore, the objectives of this study are (1) to assess the environmental suitability of the environment for the development of cattle ranching that is grazed and stacked; (2) to analyze the potential of forage source of fodder and bearing capacity for beef cattle farming; (3) to analyze the centers of activity of development of beef cattle; (4) to prepare direction and strategy of beef cattle development in Blora Regency.
\end{abstract}

\section{Introduction}

Continuous and targeted development of the livestock sector has contributed to regional development, directly in the formation of Gross Regional Domestic Product (PDRB), employment absorption, income generation, and indirectly through the creation of conditions conducive to the implementation of development and synergistic relationships with Other sectors [1]. Along with the increasing population, there is an increasing demand for food. Therefore, the availability of food supplies is needed (especially the continuity of supply availability) both from plants and animals. Increased public awareness of nutrient fulfillment encourages increased demand for food derived from animal protein such as meat derived from ruminants (beef, buffalo, sheep and goats).

Availability of meat supply is generally related to the number and production of livestock in a region. However, the number and production of livestock is not only indicated by the number of livestock population, but also related to its productivity. This needs to be considered to keep the demand for livestock products (meat) can be fulfilled. Therefore, a sustainable livestock development is needed to increase livestock production and productivity [2]. The main objective of livestock development is to improve the supply of safe, healthy, whole, halal (ASUH) animal products and farmers' welfare through sustainable competitive livestock policies and programs, optimizing the utilization of local resources.
Livestock ruminannsia that have high economic value in Indonesia is beef cattle. Nevertheless, the number of beef cattle available in Indonesia is still far from meeting the demand for meat for the community. The availability of national beef to date is still experiencing a deficit of 220 thousand tons, so it must be overcome with imports [3]. Rouf et al [4]stated that beef imports are relatively larger compared to other types of meat imports. This is reinforced by data that beef imports accounted for $21.44 \%$ of the total value of livestock imports while the value of livestock imports constituted $18.29 \%$ of the total value of agricultural products imported nationally.

Based on the data of average population of beef cattle in 2011-2015 seen that 10 provinces contribute up to $78.49 \%$ of the total beef population in Indonesia. Center population of beef cattle in Indonesia is found in three provinces, namely: East Java, Central Java and South Sulawesi. Blora Regency is one of the areas in the Province of Central Java with the largest number of large livestock, primarily beef cattle. Blora Regency has a population of 199.584 beef cattle. Agricultural waste results in Blora Regency can be used as supporting the availability of feed for livestock sector. This is supported by the availability of abundant feeding feed or carrying capacity of 236,242 AU consisting of 152,485 AU from agricultural waste, 83,029 AU of field grass and 729 AU of superior grass [3]. The carrying capacity of the area for livestock

\footnotetext{
* Corresponding author: budibudisan8@gmail.com
} 
development is demonstrated by the ability of the region to produce feed, especially forage that can accommodate and meet the needs of a number of livestock populations [5].

Refers to the Minister of Agriculture No. $41 /$ Permentan / OT.140 / 9/ 2009 concerning Technical Criteria Appropriation Region Agriculture, explained that the area of the farm must have the following characteristics: (1) the location refers to the RTRW provincial and district / city and refers to the suitability of land, (2) was built and developed by the government, local government, private and / or public in accordance with the biophysical, social, economic and environmental, (3) based on livestock commodities featured national and local and / or strategic commodities, (4) development of farmers groups and business groups, (5) can be integrated on other cultivated areas, (6) supported by the availability of water, food, technology, institutional, and market. The regulation refers to the development of animal husbandry in Blora need to consider several aspects such as the environmental aspects as a vehicle for raising livestock and carrying in it as well as socioeconomic aspects as a driver of growth regions.

Based on data from BPS Blora Regency in 2016, the population of beef cattle in Blora Regency has been increasing for the last three years. In 2013 the number of beef cattle by 198,806 tails, in 2014 of 199.584 tails and in 2015 to 211,559 tails. The population of beef cattle is spread in 16 sub-districts with the largest concentration in the territory of Todanan Sub-district [6].

Livestock development is actually influenced by several factors namely physical factors, socio-cultural and economic. Physical factors are influenced by two things: genetic factors and environmental factors, while socio-cultural and economic factors are more influenced by human resources. Genetic and environmental factors affect the performance of the livestock itself. Livestock usually shows optimal physical condition if it has superior genetic properties and is supported by the suitability of growing cattle. Environmental factors also affect the growth of cattle between temperature, air humidity and solar radiation [7]. Kadarsih [8] added that the difference in altitude of the place affects the performance of cows. French [9] argues that the richness and composition of grassland species provide forage quality and potential benefits to livestock so as to meet the nutritional requirements of beef.

Socio-cultural factors that influence the development of livestock is the behavior of farmers in raising livestock. The farmer's response in raising beef cattle is influenced by business scale, farmer's condition, and maintenance objectives [10]. An enterprise is considered profitable if the business is economically feasible, meaning it can provide shortterm profits and can be a long-term investment. Socio- cultural and economic factors are also related to the physical factors of the region in determining the success of beef cattle farming. The placement of livestock in a region should consider the suitability of land, the availability of forage feed, agricultural waste, and skilled human resources [11]. Physical (environmental), social, and economic factors are interrelated systems of one another.

Based on the potential of the region in Blora Regency, it is necessary to assess the natural characteristics of the land for the development of beef cattle farming. Evaluation of the physical (environmental), social and economic factors is closely related to the development planning of land-based cattle breeding cattle. This evaluation can be a development direction that is able to encourage the acceleration of regional development while maintaining environmental sustainability.

\section{Materials And Methods}

The research will be conducted in Blora Regency, Central Java Province. The data used in this study include primary data and secondary data. Primary data was obtained through questionnaires and interviews to respondents. Secondary data used consist of tabular data and spatial data obtained from related government agencies. Table 1 shows the relationship between objectives, data types, analysis techniques and outputs.

\subsection{Land Suitability for Cattle Development}

Land as an ecological base of feed support and cultivation environment should be optimized utilization. Optimal land for the development of beef cattle is a land that is ecologically capable of producing sufficient forage feed, quality and continuous. There is a close relationship between land, livestock and fodder. Therefore, the development of agribusiness areas need to consider the suitability of land and agro climate that support the advantages of the location concerned.

Land plays an important role in agricultural systems. Land serves as a place of production activity and is a factor in the production of livestock, especially as a source of animal feed. The interaction of livestock with land consists of three aspects: (a) biological adaptation of livestock, (b) the ability of land to produce livestock feed, and (c) pattern of maintenance and capacity of existing area [12]. The livestock industry in Asia relies heavily on land resources as a key input to the raw crude fiber forage feed that is needed and can be supplied from local sources [13]. 
Table 1. Relationship between objectives, data types, analysis techniques and outputs.

\begin{tabular}{|c|c|c|c|c|c|}
\hline No & Purpose & Data Type & Data Source & Technique Analysis & Output \\
\hline 1. & $\begin{array}{l}\text { Assessing the } \\
\text { suitability of the } \\
\text { ecological } \\
\text { environment for } \\
\text { the development } \\
\text { of beef cattle } \\
\text { farms in Blora } \\
\text { Regency }\end{array}$ & $\begin{array}{ll}- & \text { Land use map } \\
- & \text { Land resources } \\
& \text { map of Java } \\
& \text { Island } \\
- & \text { Climate data and } \\
& \text { rainfall }\end{array}$ & $\begin{array}{ll}\text { - } & \text { Blora regional } \\
\text { planning agency } \\
\text { - } & \text { Puslittanak } \\
\text { - } & \begin{array}{l}\text { Dinas PDSAP } \\
\text { district Blora }\end{array}\end{array}$ & $\begin{array}{ll}\text { - } & \text { Overlay SIG } \\
\text { - } & \text { Matching }\end{array}$ & $\begin{array}{l}\text { - Map of ecological } \\
\text { conformity of beef } \\
\text { cattle development }\end{array}$ \\
\hline 2. & $\begin{array}{l}\text { Analyze the } \\
\text { potential of forage } \\
\text { source of forage } \\
\text { and the carrying } \\
\text { capacity of forage } \\
\text { for beef cattle in } \\
\text { Blora Regency }\end{array}$ & $\begin{array}{ll}- & \text { Land use map } \\
- & \text { Data in } \\
\text { agricultural crop } \\
\text { production } \\
\text { - } & \text { Livestock } \\
\text { population data }\end{array}$ & $\begin{array}{ll}- & \text { Bappeda } \\
\text { - } & \text { BPS } \\
\text { - } & \text { Animal husbandry } \\
& \text { department }\end{array}$ & $\begin{array}{ll}- & \text { Overlay SIG } \\
- & \text { Matching } \\
- & \text { Analysis } \\
& \text { availability } \\
\text { forage }\end{array}$ & 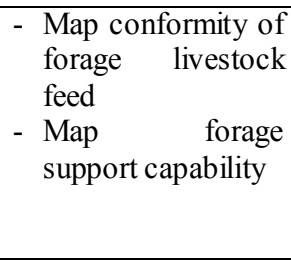 \\
\hline 3. & $\begin{array}{l}\text { Analyzing the } \\
\text { centers of activity } \\
\text { of the } \\
\text { development of } \\
\text { beef cattle in } \\
\text { Blora Regency }\end{array}$ & $\begin{array}{ll}- & \text { Livestock } \\
\text { population data } \\
\text { - } \\
\text { Commodity } \\
\text { price data of } \\
\text { livestock }\end{array}$ & $\begin{array}{l}\text { - Animal husbandry } \\
\text { department } \\
\text { - BPS }\end{array}$ & $\begin{array}{ll}- & \text { Regional } \\
\text { centralization } \\
\text { analysis }\end{array}$ & $\begin{array}{l}\text { - } \text { The value } \\
\text { convergence of } \\
\text { beef cattle farming } \\
\text { activities }\end{array}$ \\
\hline 4. & $\begin{array}{l}\text { Develop strategies } \\
\text { and direction of } \\
\text { development of } \\
\text { beef cattle in } \\
\text { Blora Regency }\end{array}$ & $\begin{array}{llr}\text { - } & \text { Data from } \\
\text { interview } & \text { / } \\
\text { questionnaire } \\
\text { Maps of } \\
\text { overlay results } \\
\text { of ecological, } \\
\text { forage, and } \\
\text { carrying } & \\
\text { suitability } & \end{array}$ & - Interview & $\begin{array}{ll}- & \text { Analysis } \\
\text { Hierarchy process } \\
-\quad \text { SWOT }\end{array}$ & $\begin{array}{l}\text { - Directive of beef } \\
\text { cattle development } \\
\text { in District Blora }\end{array}$ \\
\hline
\end{tabular}

Land suitability is the state or level of suitability of a plot of land for a particular use. Land suitability at the level of the order is divided into two namely Suitable (S) for suitable and (Non Suitable / N) land for unsuitable land. Land suitability for livestock, especially ruminants should be determined in an effort to increase productivity for large scale businesses, livestock industry, or small businesses (community farms) [14]. Based on the land requirement for livestock, it is known as land base agriculture. Landbased livestock business is a cattle business with its feed components consisting mostly of forage crops (grass and leguminous). Therefore, land is an important factor as the environment and feed support.

Farming cultivation area at this time feels increasingly difficult to find, because of the increasing competition of land use. On the other hand, the need and consumption of meat is increasing as the population grows and the welfare of the population is getting better. Associated with the spatial arrangement, the area intended for the livestock business should refer to the Regional Spatial and Regional Plans (RTRW) in accordance with Permentan. 41 of 2009 on Technical Criteria Area of Agriculture Allotment.

\subsection{Environmental factors (ecology) that affect the development of beef cattle}

The development of ruminant livestock is influenced by genetic and environmental factors. Genetic factors affect the quality of livestock seeds (offspring) produced while the appearance (performance) of production and productivity is more influenced by environmental factors. The genetic factor of livestock determines the ability of a livestock, while the environmental factor provides an opportunity for the livestock to display its ability [15].

Environmental factors affecting livestock can be direct or indirect. Direct environmental influences include production levels (through basal metabolism), food consumption, food rate movement, maintenance needs, growth reproduction, and milk production, whereas indirect environmental influences are related to the quality and availability of food. Environmental factors are factors that have a considerable effect on the level of production.

Environmental factors that affect the physiology of livestock, among others, climate factors. Temperature and air humidity are two climate factors that influence dairy cattle production, because this factor can cause balance changes in the balance of heat in the body of livestock, water balance, energy balance, and balance of livestock behavior. The ambient temperature corresponds to the altitude of a place. The higher the location of the area from the sea surface will be the lower daily air temperature.

Optimal environmental temperature for livestock growth varies between species of livestock. The environmentally comfortable thermo netral / temperature zone for European cattle ranges from 13$18^{\circ} \mathrm{C}$ (McDowell 1974) and 4-25 ${ }^{\circ} \mathrm{C}$ (Yousef). Frisian Holstein $(\mathrm{FH})$ cows exhibit the best production 
performance when placed at ambient temperature of $18.3^{\circ} \mathrm{C}$ with $55 \%$ moisture [16]. The relation between temperature and humidity is called Temperature Humidity Index (THI) and THI application can show the effect of temperature and humidity on stress level in livestock. Stressed cattle will usually make physiological adjustments and behavior. Longer heat stress on cattle will usually have an impact on increased drinking water consumption, decreased milk production, increased urine volume, and decreased feed intake.

In addition to temperature and humidity, rainfall, and long drought also affect the livestock life. The number and pattern of rainfall per year affect the productivity of livestock. The length of the dry season shows the level of water availability as a medium that supports life with the ground material from the soil. Topographic factors that affect the growth of livestock is the height of the place and the slope (slope). The percentage of slope turned out to be a limiting factor because the higher the percentage further narrowed the chances of livestock to flourish [17].

\subsection{Suitability of Forage Livestock Feed}

Beef cattle are one of ruminants and are herbivores. Herbivorous cattle require forage as food. Beef cattle require forage for more than $60 \%$ of all food consumed, both fresh and dried. Therefore, the provision of forage feed that is sufficient and has a high quality needs to get the main attention. Thus the location for the development of ruminant livestock should also be supported by the availability of quality feed.

Feed is one of the production inputs that determine the success of livestock business because it directly affects the productivity and efficiency. In ruminants, forage for feed is still a major component of the feed system and is a relatively inexpensive source of feed in most agro-ecosystems in Indonesia. Forage in the tropics like Indonesia tends to have lower nutritional quality than forage in temperate regions, due to the high proportion of fiber, low protein content and the potential deficiency of some mineral elements. In addition, its availability fluctuates considerably, primarily due to the effects of rainfall. The quantity and quality of forage will decrease during the dry season and cause the production of livestock to decrease drastically. The availability of feed crops that have high nutritional quality and are able to grow throughout the year are expected to overcome these fluctuations [18]. On the other hand, ruminant livestock can utilize the remaining agricultural produce and its follow-up products in the form of forage from the annual crop to meet the needs of feed. With the management of a good farming system, then some of the feed can be met from farmland. Based on the needs of livestock and forage production, every one hectare of dry land can support the needs of 2-6 cows or 16-30 sheep / goats, depending on the applied cropping pattern.
The ownership of livestock (especially ruminants) in each farming family is generally limited to only $3-5$ sheep / goats or $1-2$ cows / buffaloes and this is related to limited land and capital ownership. Even if sufficient capital, the availability of domestic workers will limit the increase in the amount of livestock raising, in which case there is competition between the forage seekers with energy for cultivation activities. In this regard, it is necessary to consider an effort that can streamline the system and crop production and livestock cycles, for example by storing and treating agricultural waste as the main feed source [19].

Agricultural waste is a by-product of food crop processing whose production is highly dependent on the type and number of planting areas or cropping patterns of food crops in a region [20]. Further explained some types of agricultural waste that can be used as animal feed ingredients include: rice straw, corn straw, peanut stover, and sugar cane. The yield of palawija plant waste is generally higher in nutritional value than rice straw or corn straw. Utilization of agricultural waste for livestock will support the integration of livestock business with the agricultural business of both food crops, horticulture and plantation.

Lack of forage feed in the dry season, is a routine problem every year for farmers who raise ruminant livestock. In ruminant livestock rations, grass is more widely used because in addition to cheaper is also more easily obtained. In addition, grasses have higher production and are more resistant to defoliation pressure (cutting and grasping). To increase the production and productivity of livestock, the availability and continuity of forage of fodder is necessary. For that we need to realize the existence of land used as forage gardens fodder and grazing.

The technical standards for extending grazing areas according to the Directorate General of PSP (2013) are as follows: (a) the land for developing grazing land is on relatively fertile soil; (B) the slope / topography of the pasture land up to $15 \%$; (C) the slope / topography of the land for expansion of forage forage area maximum of $40 \%$ (d) grazing area at least 10 ha per expanse; (E) planted grasses are in grass and 20 to $25 \%$ of the grazing area covered by cut grass [21].

\subsection{Land carrying capacity}

Carrying capacity indicates the enormous environmental capacity to support animal life, expressed in the number of tails per unit area of land. The number of animals that life can support depends on the biomass (plant organic material) available to animals. Carrying capacity is determined by the abundance of plant organic material formed in the process of photosynthesis per unit area and time, called primary productivity.

The determination of environmental carrying capacity shall be contained in the Regulation of the State Minister of the Environment Number 17 Year 2009 on Guidelines for the Determination of the 
Capacity of the Environment in Spatial Planning, which is done by knowing the capacity of the natural environment and resources to support human activities / residents who use space for their survival. The magnitude of environmental carrying capacity in a place is influenced by the condition and characteristics of the resources contained in the expanse of the space in question. The carrying capacity of the land is related to the availability and need of land that can meet the needs of biological production for the people living in a region [22].

Land carrying capacity is determined by many factors. Biophysical, social, economic, and cultural factors influence each other. Carrying capacity depends on the percentage of land that can be used for certain sustainable and sustainable allocations. The percentage of land is determined by the suitability of land for a certain designation. According Ardhani [23], the carrying capacity of the region to livestock is the ability of the region to accommodate a number of livestock population optimally, which is very specific between agro-ecosystems. With this understanding then:

a. The carrying capacity of the territory against traditional livestock is the ability of the region to produce feed, especially in the form of forages that can be sufficient for the needs of a number of livestock population both in the form of fresh and dry without going through special processing and addition. The carrying capacity is derived from the total forage of indigestible feed available to a number of livestock populations in the region by considering the value of other benefits optimally.

b. Real carrying capacity is the ability of land in the area concerned to produce forage feed available and commonly used and affordable utilization.

c. The potential carrying capacity is the ability of the land to produce forages in the form of opportunities for development, cultivation, and processing (save pruning).

\subsection{Geographic Information system}

Geographic information systems (GIS) became one of the most widely used tools for spatial analysis. Geographic information systems are literally defined as a component consisting of hardware, software, geographic data and human resources that work together effectively to capture, store, repair, update, manage, manipulate, integrate, analyze and display data in a Geographic-based information. SIG is a system consisting of various components that can not stand alone [24].

The main components of GIS are computer systems, geospatial data, and users. The computer system for GIS consists of hardware, software, and procedures for the preparation of data entry, processing, analysis, modeling, and viewing of geospatial data. Geospatial data sources are digital maps, aerial photographs, satellite images, statistical tables, and other documents relating to the data to be processed. The user as a target to select the required information, create standards, create an efficient updating schedule, analyze the results issued for the intended use and plan the application.

The use of GIS in the livestock sector has been developed by academics and overseas scientists, among others: information on variations of grazing and excretion behavior on ruminant species, land use type, lawn gardening, and grazing management with agropastura systems in West Nigeria [25]. Impact on the adequacy of water in cattle grazing in South Georgia [26], parameter estimates of several factors in livestock integration systems in West African savannas [27], and analyzes the application of technology and land use on dairy farms in Kenya [28].

\section{Conclusion}

Based on the potential of the region in Blora Regency, it is necessary to assess the natural characteristics of the land for the development of beef cattle farming. Evaluation of the physical (environmental), social and economic factors is closely related to the development planning of land-based cattle breeding cattle.

\section{References}

1. Department of Animal Husbandry and Animal Health of Central Java Province, Masterplan of Livestock Area Development in Central Java Province. Semarang: Department of Animal Husbandry and Animal Health of Central Java Province, 2016.

2. E. Suhaema, "Area Analysis For The Development Of Beef Cattle In Cianjur District," Institut Pertanian Bogor, 2014.

3. Kementan, Beef Outlook. Jakarta: Ministry of Agriculture RI, 2016.

4. A. A. Rouf, Daryanto, and Fariyanti, "Business Competitiveness of Beef Cattle in Indonesia: Domestic Approach Resources Cost," Wartazoa, vol. Vol.24, no. 2, pp. 97-107, 2014.

5. Sumanto, E. Juarini, Wibowo, and Ashari, "Potential Areas For The Dissemination And Development Of Animal Husbandry In Yogyakarta Special Region," Semin. Nas. Peternak. dan Veieriner, 2000.

6. BPS, Blora In Figures 2016. Blora: Central Bureau of Statistics of Blora Regency, 2016.

7. N. Silanikove, "Effects of Heat Stress on the Welfare of Extensively Managed Domestic Ruminants," Livest. Prod. Sci., vol. 67, no. October, pp. 1-18, 2000.

8. S. Kadarsih, "Performance of Bali Cattle Based on Elevation Place in Bengkulu Transmigration Area : II. Reproductive performance," J. Penelit. $U N I B$, vol. 10, no. 2, pp. 119-126, 2004.

9. K. E. French, "Species Composition Determines Forage Quality and Medicinal Value of High Diversity Grasslands in Lowland England," Agric. Ecosyst. Environ., vol. 241, pp. 193-204, 2017. 
10. Rusdin, "Several Influential Factors Against Community Responses Cattle Breeding In Parigi Moutong District," J. Agrol., vol. 16, no. 4, pp. 301-308, 2009.

11. Atmiyati, "Carrying Support Forage Support to Livestock Development in Sambas District," Temu Tek. Nas. Tenaga Fungsional Pertan., pp. 96-100, 2006.

12. Suharyanto, "Development Strategy of BuffaloBased Plantation Oil Palm Plantation in Bengkulu Province," Bengkulu, 2006.

13. N. Lasmawati, "Swot Analysis of Ruminant Animal Husbandry Development Based on the Potency of Forage Feed Using Visual Basic Programming Language 6.o," Bogor, 2006.

14. S. Hardjowigeno and Widiatmaka, Evaluation of Land Suitability and Land Use Planning, Printed 2. Yogyakarta: Gadjah Mada University Press, 2011.

15. G. A, K. Jamal, and C. Sumantri, "Estimation of Body Weight Through Morphometric analysis with Best Regression Approach Best - Subset on Garut Sheep Type Pedaging, Agile and Cross," pp. 1-6, 2008.

16. A. Yani, H. Suhardiyanto, R. Hasbullah, and B. P. Purwanto, "Analysis and Simulation of Air Temperature Distribution on Dairy Cage Using Computational Fluid Dynamics (CFD)," Media Breeders., vol. 30, no. 3, pp. 218-228, 2007.

17. N. Rusmana, Atmiyati, and Ridwan, "Making Ecological Conformity Map For Ruminant Livestock On The Scale of Review," Temu Tek. Nas. Tenaga Fungsional Pertan., 2006.

18. Haryono, Indigofera As Animal Feed. Jakarta: Ministry of Agriculture, 2013.

19. K. Diwyanto, B. Prawiradwiputra, and D. Lubis, "Integration of Crops in the Development of Agribusiness Competitiveness, Sustainable and Sourced," Pros. Semin. Nas. Teknol. Peternak. dan Vet., vol. 1, no. 1, pp. 17-26, 2002.

20. H. Makkar, "Applications Of The In Vitro Gas Method In The Evaluation Of Feed Resources, And Enchancement of Nutritional Value Of
Tannin-Rich Tree/Browse Leaves and AgroIndustrial By-Products," Dev. F. Eval. Anim. Feed Supplementation Packag. Prooceeding Final Rev. Meet. An IAEA Tech. Coop. Reg. AFRA Proj. Organ. By Jt. FAO/IAEA, pp. 23-40, 2002.

21. Ditjen PSP, Technical Guidelines for Extension of Farming Areas. Jakarta, 2014.

22. KLH, Guidance on Determination of Environmental Support Capacity in Spatial Planning. Jakarta: Ministry of Environment, 2009.

23. F. Ardhani, "Potential Areas for Livestock Development in Bulungan District, East Kalimantan Province," EPP. Vol.5. No.1. 2008, vol. 5, no. No.1, pp. 36-43, 2008.

24. J. T. Puntodewo.A, S.Dewi, "Geographic Information System for Natural Resource Management," Cent. Int. For. Res., no. 2003, 2003.

25. E. Schlecht, P. Hiernaux, I. Kadaouré, C. Hülsebusch, and F. Mahler, "A spatio-temporal analysis of forage availability and grazing and excretion behaviour of herded and free grazing cattle, sheep and goats in Western Niger," Agric. Ecosyst. Environ., vol. 113, no. 1-4, pp. 226-242, 2006.

26. M. M. Colby and Y. J. Johnson, "Potential uses for geographic information system-based planning and decision support technology in intensive food animal production," Anim Heal. Res Rev, vol. 3, no. 1, pp. 31-42, 2002.

27. V. M. Manyong, I. Okike, and T. O. Williams, "Effective dimensionality and factors affecting crop-livestock integration in West African savannas: A combination of principal component analysis and Tobit approaches," Agric. Econ., vol. 35, no. 2, pp. 145-155, 2006.

28. S. J. Staal, I. Baltenweck, M. M. Waithaka, T. deWolff, and L. Njoroge, "Location and uptake: integrated household and GIS analysis of ntechnology adoption and land use, with application to smallholder $\backslash$ ndairy farms in Kenya," Agric. Econ., vol. 27, pp. 295-315, 2002. 